\title{
USE OF POLLUTION BIOINDICATORS FOR FLUORIDE IN THE VICINITY OF COAL THERMOELECTRIC POWER PLANTS
}

\author{
Erico M. M. Flores and Ayrton F. Martins* \\ Departamento de Quimica \\ Universidade Federal de Santa Maria \\ Santa Maria, RS, BRASIL 97119-900
}

\begin{abstract}
Determination of fluoride in environmental samples of pasture and honey lead to the conclusion that these materials may be used as pollution bioindicators in areas of industrial activity. Concentrations of fluoride determined in recent times are above reference values. This observation is reinforced by the occurrence of various cases of bone deformation (fluorosis) and dental problems of ruminants in the area. A synergetic ejfect of fluoride on the abrasion of coal ash deposited on graze lands is also observed.

KEYWORDS: Fluoride, Pollution Bioindicators, Pasture, Honey.

\section{RESUMO}

A determinaço de fluoreto em amostras de pastagem e mel permite. concluir que estas matrizes podem ser utilizadas como bioindicadores de poluigão em zonas de atividade industrial. Valores determinados em épocas mais recentes encontram-se acima de valores de referência. Esta constatafão è reforgada pela ocorrência de diversos casos de deformacão óssea (fluorose) e acentuado desgaste dentärio em ruminantes nas imediagões. Verijicou-se, também, um efeito sinergético da abrasâo da cinza de carvão depositada com a agão do fluoretio sorvido na pastagem.
\end{abstract}

\section{INTRODUCTION}

Among the common air contaminants, fluoride is generally considered the most dangerous phytotoxic agent, even when polluting in trace amounts ${ }^{1}$. Plants grown in areas contaminated by fluoride show a series of physiologic injuries caused by the absorption of fluoride $2,3,4$.

The intensive use of coal in the generation of therroelectricity is along with the processing of phosphate minerals a very
important: source of fluorine dispersion in the environment $5,6,7$. Fluoride concentrations above $100 \mathrm{ppm}$ are common in mineral $\operatorname{coal}^{8}, 9$. During combustion, this air pollutant is volatilized and expelled through the chimney along with fly ${ }^{\prime}$. ash and gases 10 .

* Author to whom correspondence should be addressed. 
Under the influence of climactic factors, the emitted fluorine returns to the soil in the form of fluoride, it is deposited and interacts with the components of the biosphere (watex, soil, vegetation, fauna, etc.) 11 .

The concentration of fluoride in environmental materials can be an indicator of the degree of environmental contamination. It is a function of regional climactic factors and the distance from the source of the emission 12,13 .

This paper deals with the determination of fluoride concentration in samples of pasture and honey collected for a period of three years (1987-90) using ion-selective electrode tecnhiques. Samples were collected in the vicinity of two thermoelectric power plants located in Southern Brazil. One is Usina Termoelétrica Presidente Medici (UTPM/446 MW), located at Candiota, Bage , Rio Grande do Sul. The other is Usina Termoelétrica de Charqueadas (UTC/72 MW), situated at Charqueadas, Rio Grande do Su1. In both areas, besides the generation of thermoelectricity, coal mining is also practiced - in open pits in Candiota and $300 \mathrm{~m}$ deep mines in Charqueadas.

The experimental results obtained by the analysis of the environmental samples were submitted to statistical treatment in order to verify the behavior of concentration (dependent variable) as a function of three factors: distance from the plant, time of collection of samples and direction of collection of samples.

\section{MATERIALS AND METHODS}

The aerial parts of predominant forage grasses (Panicum graminae, Piptochaetium montevidense, Paspalum notatum, Aristida sp. e Eupatorium bunitfolium) were collected within a $1.3-11.8 \mathrm{~km}$ range of UTPM (63 samples) and $0.5-5.6 \mathrm{~km}$ of UTC ( 29 samples) in the direction of prevailing winds ( $S W$ in Candiota and $S E$ in Charqueadas). The sampling was restricted to previously determined areas, with the plants at the center and angles of 559 and 1109 . (See Figure 1).

The samples of honey were collected in the places of production within a range of $0.5-22.0 \mathrm{~km}$ (17 samples) from UTPM and $3.5-32.0 \mathrm{~km}(13 \mathrm{samples})$ from UTC in the areas of sampling previously determined.

Reference forage grass samples were collected at about $50 \mathrm{~km}$ from UTPM and $20 \mathrm{~km}$ from UTC in a direction contrary to prevailing winds. Reference samples of honey were obtained from different localities, in areas not affected by anthropogenic processes.

The pasture material collected was reduced to maximum lengths of $2 \mathrm{~mm}$ using a micromill and dried in an oven at 509 C for 5 hours. Two-gram samples of the dried material was subsequently washed for 2 hours with $70 \mathrm{ml}$ of $0.46 \% \mathrm{HNO}_{3}$. The solution was filtered using filter paper and the volume was 
SBJ CHEM., Vol. 1, No. 1, 1993

E.M.M. Flores \& A.F. Martins

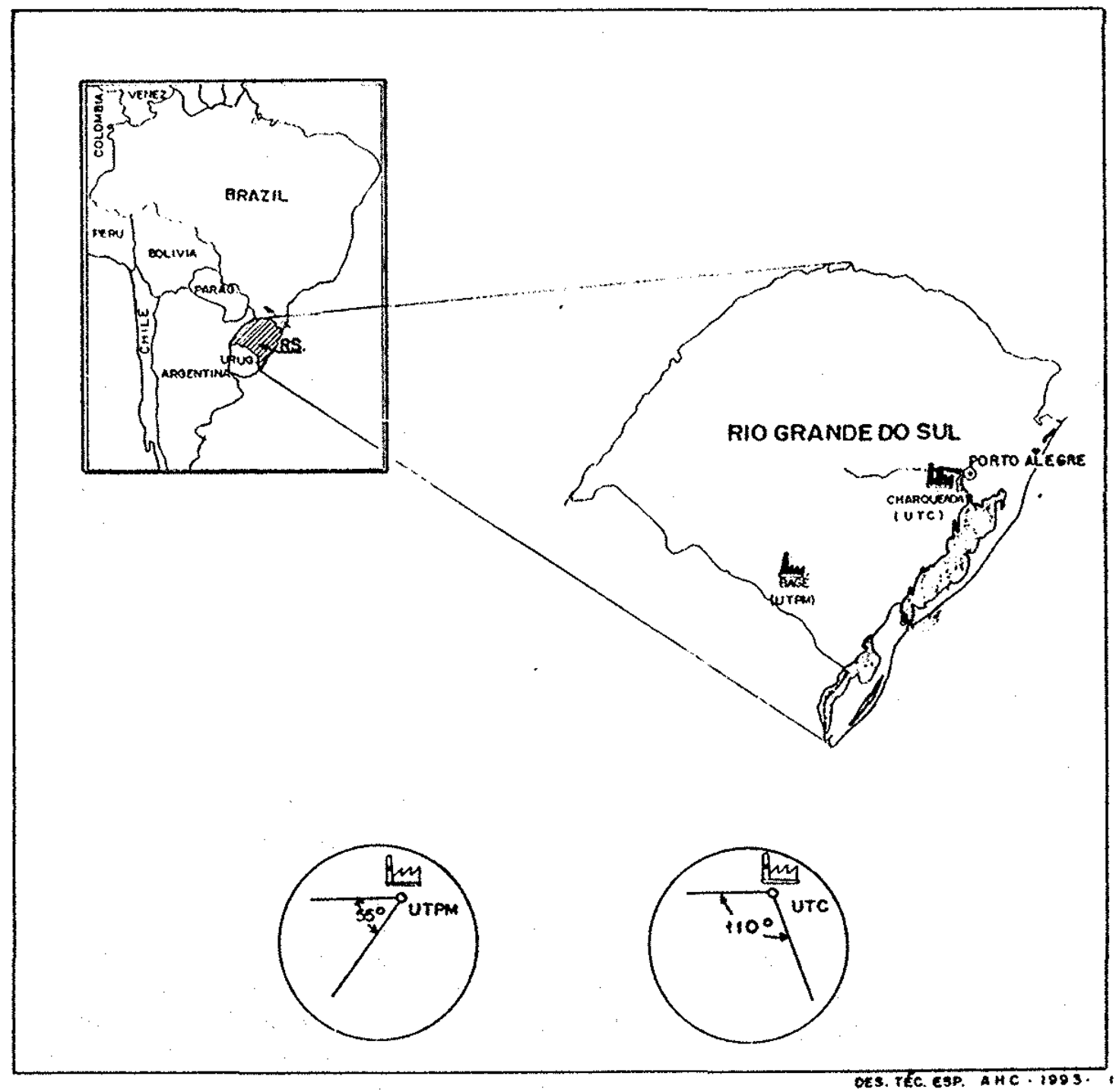

FIGURE 1. SAMPLING AREAS: CANDIOTA ( UTPM - USINA TERMOELETRICA PRESIDENTE MEDICI) AND CHARQUEADAS ( UTC - USINA TERMOELETRICA DE CHARQUEADAS ), RIO GRANDE DO SUL, BRAZIL . 
completed to $100 \mathrm{~m} 1$ with $0.46 \% \mathrm{HNO}_{3}$ (Solution $1 ; \mathrm{F}^{-}$extracted). The residue was dried at $509 \mathrm{C}$ for 8 hours and transferred to a $250 \mathrm{ml}$ PTFE container and subjected to acid digestion under pressure. After adding $10 \mathrm{ml}$ of conc. $\mathrm{HNO}_{3}$ and $2 \mathrm{ml}$ of $30 \% \mathrm{H}_{2} \mathrm{O}_{2}$, the system was hermetically sealed and heated at 150 \% C: for 6 hours. After cooling and relieving the pressure, $5 \mathrm{ml}$ of conc. $\mathrm{NH}_{4} \mathrm{OH}$ were added. The solution was filtered and diluted to $100 \mathrm{~m} 1$ with $0.46 \% \mathrm{HNO}_{3}$ (Solution $2 ; \mathrm{F}^{-}$absorbed). The treatment of the samples of honey was also done using high pressure and PTFE containers. To a $2 \mathrm{~g}$ sample of honey $7 \mathrm{ml}$ of conc. $\mathrm{HNO}_{3}$ and $\mathrm{l} \mathrm{ml}$ of $30 \% \mathrm{H}_{2} \mathrm{O}_{2}$ were added and the system was heated at $1309 \mathrm{C}$ for $4 \mathrm{hr}$. Subsequently the solution was cooled, the system opened, $.3 \mathrm{ml}$ of concentrated $\mathrm{NH}_{4} \mathrm{OH}$ were added, followed by dilution to $50 \mathrm{ml}$ with $0.46 \%$ $\mathrm{HNO}_{3}$ (Solution $3, \mathrm{~F}^{-}$, honey).

Solutions 1,2 and 3 were analyzed by direct potentiometry using a fluoride ion-selective electrode (ISE-F- Analion F656) and a calomel reference electrode (Jena Glass B281) coupled with a Philips PW 9409 digital potentiometer. Buffer solution for total ionic strength adjustment (TAFIT) was added to the samples at $1: 1(\mathrm{v} / \mathrm{v})$ ratiol 14 and the measurements were made under constant agitation. Blank samples were also analyzed using the tecnique of standard addition.

\section{RESULTS AND DISCUSSION}

Fluorine, like other elements such as $\mathrm{Hg}, \mathrm{As}$ and $\mathrm{Se}$ passes with relative ease through electrostatic filters and for this reason thermoelectric power plants exhibit a high concentration of emission of this atmospheric pollutant (up to 75\%) 10 .

(See Table I).

Deposition of fluoride from the atmosphere is an important factor in the contamination of biosphere reservoirs. Plants are particularly affected, since they absorb fluoride easily from the air $15,16,17$. They show cellular membrane damage and leaf necrosis $18,19,20$. The absorption of fluoride from the soil is relatively low, due to its reduced mobility in this environment. Fluoride is concentrated in the aerial parts of plants, where its physiologic effects are more pronounced21,22. For this reason, bioindication of pollution can be done using only the superior parts of the plants and analysis of the roots is not necessary.

Tables"II and III show the concentration of fluoride (F- extracted, $F^{-}$absorbed and $F^{-}$total) from pastures in the regions studied as a function of distance, time of collection and direction. Individual values of total fluoride concentration surpass 30 to $40 \mathrm{ppm}$, usually refered to as a limiting value, above which there is clear indication of physiologic damages $23,24,25,26$. 
SBJ CHEM., Vol. 1, No. 1, 1993

E.M.M. Flores \& A.F. Martins

TABLE I. MATERIAL BALANCE FOR UTPM POWER PLANT! ${ }^{10}$

\begin{tabular}{cccccc}
\hline Element & $\begin{array}{c}\text { Coal } \\
(\mathrm{ppm})\end{array}$ & $\begin{array}{c}\text { Bottom Ash } \\
(\mathrm{ppm})\end{array}$ & $\begin{array}{c}\text { Light Ash } \\
(\mathrm{ppm})\end{array}$ & $\begin{array}{c}\text { Emission } \\
(\mathrm{kg} / \mathrm{d})\end{array}$ & $\begin{array}{c}\text { Losses } \\
(\%)\end{array}$ \\
\hline $\mathrm{F}$ & 169 & 48.5 & 83.5 & 1,115 & 75 \\
$\mathrm{Hg}$ & 0.76 & 0.18 & 0.43 & 4.8 & 73 \\
$\mathrm{As}$ & 2.56 & 0,05 & 0.15 & 21.7 & 97 \\
$\mathrm{Se}$ & 1.46 & 0.34 & 0.83 & 9.3 & 73 \\
\hline
\end{tabular}

Coal consumption: $10,300 \mathrm{t} / \mathrm{d}$; Effectiveness of electrostatic filters: ${ }^{-92.5 \%}$

TABLE II. CONCENTRATION (PPM) OF FLUORIDE IN SAMPLES OF PASTURE FROM CANDIOTA REGION (INDIVIDUAL VALUES). AVERAGE VALUES AND STANDARD DEVIATIONS OF TWO OR MORE DETERMINATIONS FOR EACH SAMPLE.

\begin{tabular}{lrrrr}
\hline $\begin{array}{c}\text { Time of } \\
\text { Collection }\end{array}$ & $(\mathrm{km})^{*}$ & $\mathrm{~F}^{-}$abs. & \multicolumn{1}{c}{$\mathrm{F}^{-}$ext. } & \multicolumn{1}{c}{$\begin{array}{c}\mathrm{F}^{-} \\
\text {total }\end{array}$} \\
\hline & & & & \\
November/1987 & 1.5 & $9.00 \pm 0.15$ & $44.39 \pm 0.30$ & 53.30 \\
November/1987 & 3.5 & $11.13 \pm 1.52$ & $20.65 \pm 3.42$ & 31.78 \\
November/1987 & 5.0 & $39.73 \pm 0.15$ & $5.61 \pm 0.21$ & 45.34 \\
November/1987 & 5.0 & $47.87 \pm 4.58$ & $11.91 \pm 1.57$ & 59.78 \\
November/1987 & 5.0 & $8.38 \pm 1.90$ & $2.42 \pm 1.06$ & 10.70 \\
& & & & \\
April/1988 & 1.5 & $27.82 \pm 0.84$ & $18.63 \pm 2.54$ & 46.45 \\
April/1988 & 3.5 & $16.09 \pm 1.83$ & $9.21 \pm 1.13$ & 25.30 \\
April/1988 & 4.0 & $20.23 \pm 2.75$ & $10.45 \pm 1.13$ & 30.68 \\
April/1988 & 5.0 & $15.84 \pm 1.97$ & $9.35 \pm 1.55$ & 25.19 \\
April/1988 & 5.0 & $41.23 \pm 3.96$ & $17.02 \pm 3.11$ & 58.25 \\
April/1988 & 6.0 & $18.20 \pm 0.85$ & $11.01 \pm 1.41$ & 29.21 \\
April/1988 & 6.5 & $28.42 \pm 0.48$ & $11.20 \pm 0.22$ & 39.62 \\
April/1988 & 7.0 & $29.82 \pm 0.36$ & $10.45 \pm 1.42$ & 40.27 \\
April/1988 & 9.0 & $24.63 \pm 0.18$ & $8.82 \pm 0.48$ & 33.45 \\
April/1988 & 10.0 & $18.03 \pm 2.45$ & $5.84 \pm 0.84$ & 23.87 \\
& & & & \\
August/1988 & 1.3 & $8.46 \pm 0.82$ & $3.01 \pm 0.42$ & 11.47 \\
August/1988 & 1.5 & $20.95 \pm 2.19$ & $4.60 \pm 0.35$ & 25.55 \\
August/1988 & 1.5 & $6.67 \pm 0.60$ & $2.51 \pm 0.57$ & 9.18 \\
August/1988 & 2.8 & $28.15 \pm 1.20$ & $3.04 \pm 0.15$ & 31.19 \\
August/1988 & 3.0 & $27.70 \pm 2.40$ & $3.98 \pm 0.68$ & 31.68 \\
\hline
\end{tabular}


TABLE II. (CONTINUATION)

\begin{tabular}{|c|c|c|c|c|}
\hline August/1988 & 3.0 & $7.75 \pm 1.06$ & $2.74 \pm 0.05$ & 10.49 \\
\hline August/1988 & 4.7 & $9.67 \pm 0.24$ & $3.00 \pm 0.70$ & 12.67 \\
\hline August/1988 & 5.0 & $6.65 \pm 0.71$ & $2.45 \pm 0.14$ & 9.10 \\
\hline August/1988 & 5.0 & $23.42 \pm 0.59$ & $5.05 \pm 0.21$ & 28.47 \\
\hline August/1988 & 6.7 & $10.87 \pm 0.17$ & $2.40 \pm 0.14$ & 13.27 \\
\hline August/1988 & 7.0 & $9.32 \pm 0.45$ & $3.12 \pm 0.03$ & 12.44 \\
\hline August $/ 1988$ & 7.0 & $7.05 \pm 0.21$ & $1.97 \pm 0.17$ & 9.02 \\
\hline August/1988 & 8.6 & $4.95 \pm 0.63$ & $1.93 \pm 0.11$ & 6.88 \\
\hline August/1988 & 9.0 & $12.12 \pm 0.53$ & $1.55 \pm 0.14$ & 13.67 \\
\hline August/1988 & 11.0 & $5.50 \pm 0.71$ & $1.67 \pm 0.24$ & 7.17 \\
\hline August/1988 & 11.5 & $3.95 \pm 0.35$ & $1.49 \pm 0.21$ & 5.44 \\
\hline August/1988 & 11.8 & $6.16 \pm 0.59$ & $3.26 \pm 0.13$ & 9.42 \\
\hline January/1989 & 1.3 & $8.17 \pm 0.24$ & $6.27 \pm 0.03$ & 14.44 \\
\hline January/1989 & 1.6 & $8.22 \pm 1.73$ & $2.74 \pm 0.70$ & 10.96 \\
\hline January/1989 & 1.6 & $6.77 \pm 0.10$ & $2.52 \pm 0.03$ & 9.29 \\
\hline January/1989 & 2.8 & $12.50 \pm 2.96$ & $2.07 \pm 0.11$ & 14.57 \\
\hline January/1989 & 3.1 & $15.37 \pm 0.17$ & $4.03 \pm 0.18$ & 19.40 \\
\hline January/1989 & 3.1 & $4.26 \pm 0.68$ & $2.10 \pm 0.14$ & 6.36 \\
\hline January/1989 & 4.6 & $6.00 \pm 0.28$ & $4.65 \pm 0.21$ & 10.65 \\
\hline January/1989 & 5.0 & $4.50 \pm 0.28$ & $2.25 \pm 0.21$ & 6.75 \\
\hline January/1989 & 5.0 & $4.25 \pm 0.35$ & $2.43 \pm 0.11$ & 6.68 \\
\hline January/1989 & 7.0 & $7.67 \pm 0.25$ & $3.78 \pm 0.60$ & 11.45 \\
\hline January/1989 & 7.1 & $5.05 \pm 0.28$ & $3.60 \pm 0.28$ & 8.65 \\
\hline January/1989 & 7.0 & $5.43 \pm 0.11$ & $3.33 \pm 0.18$ & 8.76 \\
\hline January/1989 & 8.2 & $14.65 \pm 0.21$ & $3.13 \pm 0.32$ & 17.78 \\
\hline January/1989 & 8.5 & $16.30 \pm 1.55$ & $3.17 \pm 0.10$ & 19.47 \\
\hline January/1989 & 11.0 & $3.87 \pm 0.53$ & $3.58 \pm 0.24$ & 7.45 \\
\hline January/1989 & 11.3 & $4.67 \pm 0.95$ & $1.96 \pm 0.24$ & 6.63 \\
\hline January/1989 & 11.8 & $4.05 \pm 0.14$ & $2.40 \pm 0.13$ & 6.45 \\
\hline August/1989 & 1.3 & $4.60 \pm 2.69$ & $2.03 \pm 0.31$ & 6.63 \\
\hline August/1989 & 1.6 & $9.20 \pm 0.08$ & $2.89 \pm 0.49$ & 12.09 \\
\hline August/1989 & 1.6 & $3.80 \pm 0.28$ & $2.45 \pm 0.97$ & 6.25 \\
\hline August/1989 & 2.8 & $6.00 \pm 0.00$ & $2.69 \pm 1.10$ & 8.69 \\
\hline August/1989 & 3.1 & $3.15 \pm 0.35$ & $1.80 \pm 0.14$ & 4.95 \\
\hline August/1989 & 3.1 & $2.75 \pm 0.35$ & $1.70 \pm 0.14$ & 4.45 \\
\hline August/1989 & 4.6 & $2.55 \pm 0.92$ & $1.80 \pm 0.08$ & 4.35 \\
\hline August/1989 & 5.0 & $3.60 \pm 1.65$ & $1.87 \pm 0.04$ & 5.47 \\
\hline August/1989 & 5.0 & $4.45 \pm 0.21$ & $2.45 \pm 0.07$ & 6.90 \\
\hline August/1989 & 7.1 & $2.48 \pm 0.11$ & $1.68 \pm 0.74$ & 4.16 \\
\hline August/1989 & 7.0 & $3.20 \pm 0.14$ & $2.50 \pm 0.00$ & 5.70 \\
\hline August/1989 & 8.5 & $2.15 \pm 0.07$ & $1.35 \pm 0.21$ & 3.50 \\
\hline August/1989 & 11.3 & $2.00 \pm 0.28$ & $1.05 \pm 0.07$ & 3.05 \\
\hline August/1989 & 11.8 & $4.05 \pm 0.21$ & $1.95 \pm 0.07$ & 6.00 \\
\hline
\end{tabular}


8BJ CHRM., Vol. 1, No. 1, 1993

E.M.M. Flores \& A.F. Martins

67

TABLE III. CONCENTRATION (PPM) OF FLUORIDE IN SAMPLES OF PASTURE FROM CHARQUEADAS REGION (INDIVIDUAL VALUES). AVERAGE VALUES AND STANDARD DEVIATIONS OF TWO OR MORE DETERMINATIONS FOR EACH SAMPLE.

\begin{tabular}{|c|c|c|c|c|}
\hline $\begin{array}{c}\text { Time of } \\
\text { Collection }\end{array}$ & $(\mathrm{km})^{*}$ & $\begin{array}{c}F^{-} \\
\text {absorbed }\end{array}$ & $\begin{array}{c}\mathrm{F}^{-} \\
\text {extracted }\end{array}$ & $\begin{array}{c}\mathrm{F}^{-} \\
\text {total } \\
\end{array}$ \\
\hline July/1988 & 1.0 & $13.00 \pm 1.03$ & $4.43 \pm 0.11$ & 17.43 \\
\hline July/1988 & 2.0 & $6.87 \pm 0.04$ & $4.05 \pm 1.20$ & 10.92 \\
\hline July/1988 & 3.0 & $4.58 \pm 0.11$ & $2.60 \pm 0.95$ & 7.18 \\
\hline July/1988 & 4.0 & $6.20 \pm 0.39$ & $2.51 \pm 0.49$ & 8.71 \\
\hline July/1988 & 5.5 & $5.57 \pm 0.26$ & $2.78 \pm 0.38$ & 8.35 \\
\hline December/1988 & 0.5 & $10.28 \pm 1.19$ & $4.53 \pm 0.78$ & 14.81 \\
\hline December/1988 & 1.3 & $6.75 \pm 1.06$ & $5.50 \pm 0.00$ & 12.25 \\
\hline December/1988 & 1.6 & $5.63 \pm 0.32$ & $2.23 \pm 0.03$ & 7.86 \\
\hline December/1988 & 2.0 & $5.28 \pm 0.26$ & $2.90 \pm 0.92$ & 8.18 \\
\hline December/1988 & 2.6 & $4.52 \pm 1.02$ & $2.93 \pm 0.25$ & 7.45 \\
\hline December/1988 & 2.8 & $5.18 \pm 0.11$ & $4.60 \pm 0.42$ & 9.78 \\
\hline December/1988 & 3.5 & $32.25 \pm 2.47$ & $4.75 \pm 0.90$ & 37.00 \\
\hline December/1988 & 3.8 & $5.15 \pm 0.85$ & $2.76 \pm 0.17$ & 7.91 \\
\hline December $/ 1988$ & 5.0 & $16.70 \pm 1.84$ & $2.03 \pm 0.32$ & 18.73 \\
\hline December/1988 & 5.5 & $5.85 \pm 0.85$ & $1.75 \pm 0.14$ & 7.60 \\
\hline June/1989 & 0.5 & $26.90 \pm 0.56$ & $27.85 \pm 0.21$ & 54.75 \\
\hline June/1989 & 1.3 & $45.55 \pm 0.35$ & $5.00 \pm 0.28$ & 50.55 \\
\hline June/1989 & 1.3 & $47.15 \pm 0.21$ & $13.55 \pm 0.07$ & 60.70 \\
\hline June/1989 & 1.6 & $13.65 \pm 0.21$ & $8.10 \pm 0.14$ & 21.25 \\
\hline June/1989 & 2.0 & $24.35 \pm 0.64$ & $8.50 \pm 0.00$ & 32.85 \\
\hline June/1989 & 2.3 & $33.10 \pm 0.28$ & $8.05 \pm 0.07$ & 41.15 \\
\hline June/1989 & 2.6 & $36.30 \pm 0.00$ & $7.13 \pm 0.18$ & 43.43 \\
\hline June/1989 & 2.8 & $21.05 \pm 0.35$ & $5.15 \pm 0.21$ & 26.20 \\
\hline June/1989 & 3.5 & $3.10 \pm 0.28$ & $3.00 \pm 0.14$ & 6.10 \\
\hline June/1989 & 3.8 & $5.25 \pm 0.07$ & $7.40 \pm 0.14$ & 12.65 \\
\hline June/1989 & 3.9 & $4.75 \pm 0.07$ & $6.70 \pm 0.42$ & 11.45 \\
\hline June/1989 & 5.0 & $4.55 \pm 0.35$ & $4.45 \pm 0.07$ & 9.00 \\
\hline June/1989 & 5.5 & $3.25 \pm 0.07$ & $6.40 \pm 0.14$ & 9.65 \\
\hline June/1989 & 5.6 & $3.65 \pm 0.22$ & $4.93 \pm 0.11$ & 8.58 \\
\hline
\end{tabular}

$F^{-}$concentration in reference samples: $F^{-}$abs $=2.26 \pm 0.02$;

$F^{-}$ext. $=1.15 \pm 0.00 ; F^{-}$total $=3.35 \mathrm{ppm}$

* Distance from UTPM 
The data in Tables II and III was submitted to two types of statistical treatment. The first one involved Analysis of Variance (ANOVA) and had as an objective to test if the factors such as distance, time of the year and/or direction of collection of samples interfere with the total concentration of fluoride in pasture. The level of significance adopted for ANOVA was $5 \%$. A comparison with the fluoride values calculated using ANOVA ( $F^{-}$test) showed that for Candiota there was a real difference between the average values of fluoride as a function of time and for Charqueadas as a function of distance. The differences in each group were identified using Tuckey's Test with a significance leve 1 of $5 \%$. (Table IV).

This means that for Charqueadas the average values of fluoride are statistically equal when grouped as a function of time and site of sampling and different when the concentrations are grouped as a function of distance.

On the other hand, in Candiota the average values of fluoride concentrations are statistically equal when grouped as function of site of collection and distance and are different and decrease when grouped as a function of the time of sampling (Figure 2). This fact can be explained by the use of new, more efficient electrostatic filters in UTPM starting with April 1988. These new filters have a higher capacity to capture the finer fraction of ash, possibly richer in fluoride.

Interestingly, the ANOVA test also showed, as expected, that the average concentrations were equal as a function of site of collection in both Candiota and Charqueadas. In Candiota this was explained by the major dispersion of the emitted fluorine due to the tall chimney $(140 \mathrm{~m})$. In Charqueadas, on the other hand, where the chimney is shorter $(60 \mathrm{~m})$ the possible explanation is the change in direction of the winds in the region.

The second statistical treatment involved identifying the average concentrations that are statistically equal as a function of time (in Candiota) and distance (in Charqueadas). Tuekey's Test, with significance levels of $5 \%$ was employed and the results are shown in Table IV.

It was shown that there are no real differences for the average values as a function of distance and direction in Candiota and time and direction in Charqueadas.

In Charqueadas, the concentration of fluoride decreases with the increase of distance from UTC. Statistically, this does not happen in Candiota, where the apparent decrease of concentration with distance from UTPM is casual and not real (Figure 2). This is in agreement with the ANOVA test and also with Tuckey's Test.

The tendency of increasing values as a function of time obtained in Charqueadas is apparent and is not confirmed by the ANOVA test. The decreasing variation of concentration in Candiota as a function of time of sampling is confirmed by the ANOVA test and may be explained by the use of new electrostatic filters, as previously mentioned. 
SBJ CHEM., Vol. 1, No. 1, 1993

TABLE IV. CONCENTRATION (PPM) OF FLUORIDE IN SAMPLES OF PASTURE FROM CANDIOTA AND CHARQUEADAS REGIONS (STATISTICAL VALUES).

\begin{tabular}{|c|c|c|c|c|c|c|}
\hline & $\begin{array}{l}\text { Lower limit } \\
(\alpha / 2=5 \%)\end{array}$ & Average & $\begin{array}{l}\text { Upper } \\
\text { limit }\end{array}$ & $\begin{array}{c}\text { Number } \\
\text { of } \\
\text { samples }\end{array}$ & $\begin{array}{c}\text { F-test } \\
\text { (calculated) }\end{array}$ & $\begin{array}{c}\text { Tukey's } \\
\text { test } \\
(\alpha=5 \%)^{*}\end{array}$ \\
\hline \multicolumn{7}{|c|}{ CANDIOTA REGION } \\
\hline \multicolumn{7}{|l|}{$\begin{array}{l}\text { Distance } \\
(\mathrm{km})\end{array}$} \\
\hline $1 \rightarrow 3$ & 14.35 & 18.58 & 22.80 & 14 & & - \\
\hline $3 \rightarrow 5$ & 17.05 & 21.28 & 25.51 & 14 & & - \\
\hline $5 \rightarrow 7$ & 10.22 & 15.23 & 20.23 & 10 & & $\cdot$ \\
\hline $7 \rightarrow 9$ & 7.77 & 12.34 & 16.91 & 12 & 1.79 & $\bullet$ \\
\hline $9 \rightarrow 11$ & 14.53 & 23.66 & 32.80 & 3 & & $\bullet$ \\
\hline $11 \rightarrow 13$ & 0.86 & 6.45 & 12.05 & 8 & & $\bullet$ \\
\hline \multicolumn{7}{|l|}{$\begin{array}{l}\text { Time of } \\
\text { Collection }\end{array}$} \\
\hline $\begin{array}{l}\text { April } \\
1988\end{array}$ & 27.51 & 33.10 & 38.70 & 8 & & $\bullet$ \\
\hline $\begin{array}{c}\text { August } \\
1988\end{array}$ & 10.70 & 14.54 & 18.37 & 17 & $23.97^{\star}$ & $\bullet$ \\
\hline $\begin{array}{c}\text { January } \\
1989\end{array}$ & 7.09 & 10.93 & 14.76 & 17 & & $\bullet \bullet$ \\
\hline $\begin{array}{l}\text { August } \\
1989\end{array}$ & 1.64 & 5.87 & 11.00 & 14 & & $\bullet$ \\
\hline \multicolumn{7}{|c|}{ CHARQUEADAS REGION } \\
\hline \multicolumn{7}{|l|}{$\begin{array}{l}\text { Distance } \\
(\mathrm{km})\end{array}$} \\
\hline $0 \rightarrow 3$ & 19.12 & 26.25 & 33.39 & 16 & & • \\
\hline $3 \rightarrow 5$ & 2.21 & 13.00 & 23.79 & 7 & $3.82^{\star}$ & • \\
\hline $5 \rightarrow 7$ & 0.00 & 10.32 & 21.97 & 6 & & $\bullet$ \\
\hline $\begin{array}{l}\text { Time of } \\
\text { Collection }\end{array}$ & & & & & & \\
\hline $\begin{array}{l}\text { July } \\
1988\end{array}$ & 0.00 & 10.51 & 23.28 & 5 & & $\bullet$ \\
\hline $\begin{array}{c}\text { Dezember } \\
1988\end{array}$ & 4.13 & 13.16 & 22.18 & 10 & 2.76 & $\bullet$ \\
\hline $\begin{array}{l}\text { June } \\
1989 \\
\end{array}$ & 20.15 & 27.77 & 35.40 & 14 & & - \\
\hline
\end{tabular}

* Significative value at level of $5 \%(\alpha=5 \%)$ 


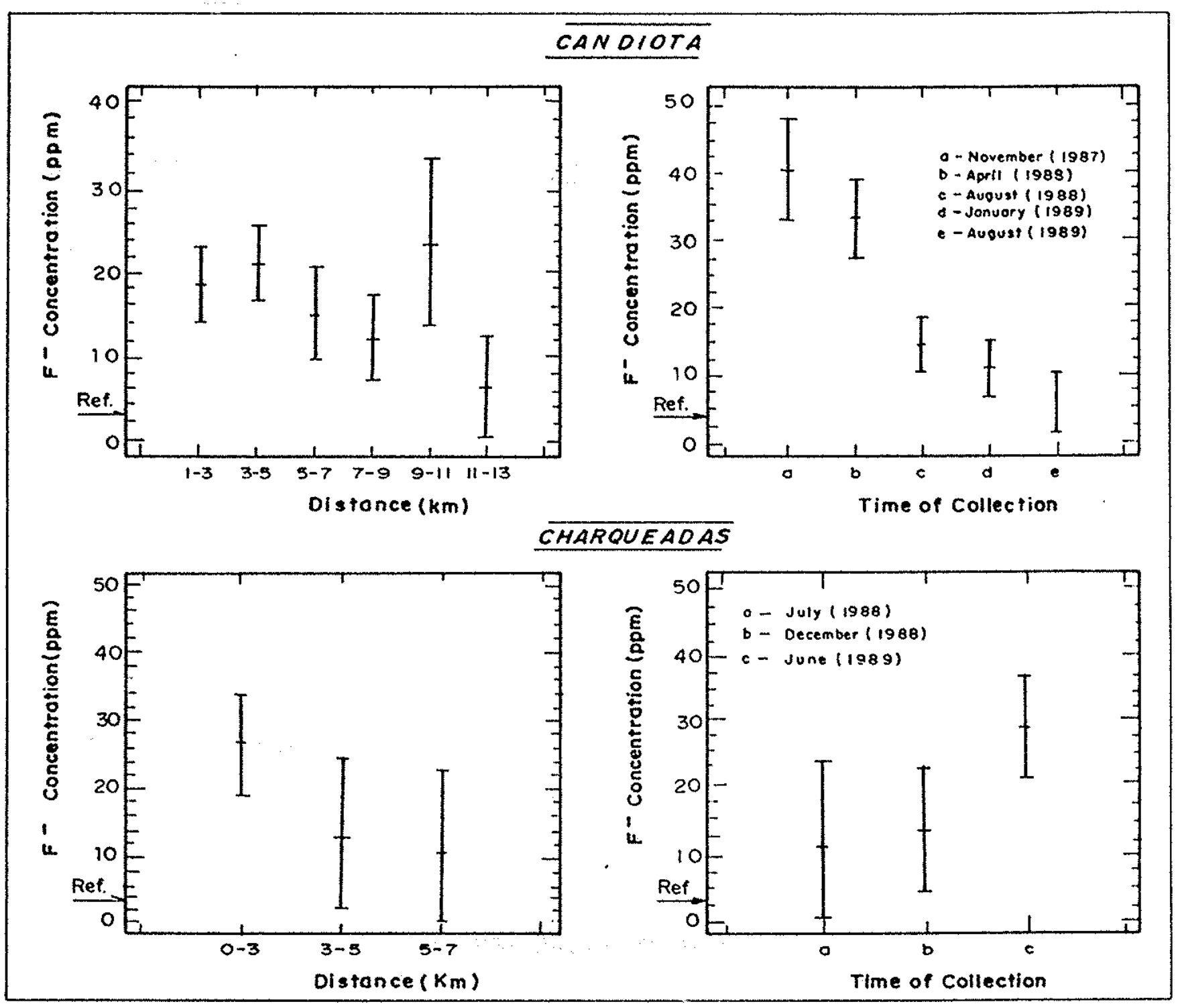

FIGURE 2. AVERAGE VALUES OF FLUORIDE CONCENTRATION (TOTAL) IN PASTURE FROM CANDIOTA AND CHARQUEADAS REGIONS AS A FUNCTION OF THE DISTANCE FROM UTPM AND UTC POWER PLANTS AND THE TIME OF COLLECTION. 
SBJ CHEM., Vol. 1, No. 1, 1993

R.M.M. Flores \& A.E. Martins

TABLE V. CONCENTRATION (PPM) OF FLUORIDE IN SAMPLES OF HONEY FROM CANDIOTA AND CHARQUEADAS REGIONS.

\begin{tabular}{|c|c|c|}
\hline \multicolumn{3}{|c|}{ CANDIOTA } \\
\hline $\begin{array}{l}\text { Distance } \\
\text { from } \\
\text { UTPM } \\
\text { (km) }\end{array}$ & $\begin{array}{l}\text { Time of } \\
\text { Collection }\end{array}$ & $\begin{array}{l}\text { Concentration } \\
\text { of Fluoride } \\
\text { (ppm) }\end{array}$ \\
\hline 4.5 & November/1988 & $4.92 \pm 0.14$ \\
\hline 4.0 & November/1988 & $8.21 \pm 0.49$ \\
\hline 6.0 & April/1988 & $4.22 \pm 0.74$ \\
\hline 8.0 & April/1988 & $4.50 \pm 1.41$ \\
\hline 12.0 & April/1988 & $4.20 \pm 1.27$ \\
\hline 0.5 & June/1988 & $1.60 \pm 0.14$ \\
\hline 6.0 & June/1988 & $1.45 \pm 0.14$ \\
\hline 8.5 & June/1988 & $8.80 \pm 0.63$ \\
\hline 12.0 & June/1988 & $1.98 \pm 0.17$ \\
\hline 10.5 & November/1988 & $7.81 \pm 2.04$ \\
\hline 12.0 & November/1988 & $1.42 \pm 0.30$ \\
\hline 12.1 & November/1988 & $1.85 \pm 0.35$ \\
\hline 22.0 & November/1988 & $1.50 \pm 0.08$ \\
\hline 22.0 & June/1989 & $1.25 \pm 0.08$ \\
\hline 11.5 & January/1990 & $1.52 \pm 10.09$ \\
\hline 12.0 & January/1990 & $1.43 \pm 10.11$ \\
\hline 22.0 & January/1990 & $1.01 \pm 10.07$ \\
\hline \multicolumn{3}{|c|}{ CHARQUEADAS } \\
\hline $\begin{array}{c}\text { Distance } \\
\text { from UTC } \\
(\mathrm{km})\end{array}$ & $\begin{array}{l}\text { Time of } \\
\text { Collection }\end{array}$ & $\begin{array}{l}\text { Concentration of } \\
\text { Fluoride (ppm) }\end{array}$ \\
\hline 3.5 & May/1988 & $6.83 \pm 0.41$ \\
\hline 15.0 & May/1988 & $1.76 \pm 0.51$ \\
\hline 20.0 & May/1988 & $5.18 \pm 0.21$ \\
\hline 4.0 & November/1988 & $5.54 \pm 1.13$ \\
\hline 4.0 & November/1988 & $1.57 \pm 0.17$ \\
\hline 4.0 & November/1988 & $3.55 \pm 3.25$ \\
\hline 4.0 & November/1988 & $1.26 \pm 0.03$ \\
\hline 4.0 & May/1989 & $0.77 \pm 0.04$ \\
\hline 6.0 & May/1989 & $1.15 \pm 0.03$ \\
\hline 6.5 & May/1989 & $0.12 \pm 0.04$ \\
\hline 18.0 & May/1989 & $0.15 \pm 0.06$ \\
\hline 32.0 & May/1989 & $5.50 \pm 0.09$ \\
\hline
\end{tabular}

Average values and standard deviations of two or more determinations for each sample

$F^{-}$concentration in reference samples: $<0,02 \mathrm{ppm}$ 
The variation of concentration as a function of direction is not statistically real and is not significant according to the ANOVA test for both power plants. In Candiota this may be attributed to a greater dispersion of the emitted fluorine, considering the high chimney $(140 \mathrm{~m})$. In Charcueadas, on the other hand, where the chimney is lower $(60 \mathrm{~m})$, the explanation given is as a function of possible variations in the direction of winds in the region.

In Candiota the average concentration of fluoride in pasture varied from 6.5 to 23.7 (as a function of distance); 5.9 to 40.2 (time of collection) and 8.3 to 15.3 ppm (direction). In Charqueadas the respective ranges were 10.3 to $26.3 ; 10.5$ to 27.8 and 16.3 to $30.5 \mathrm{ppm}$ (Table IV).

The samples of honey analyzed exhibited higher concentration of fluoride when compared to samples from non-contaminated areas. Table $V^{-\prime}$ shows the concentration of fluoride as a function of distance from UTPM and UTC at the respective times of sampling.

In Candiota, the concentration of fluoride in honey ranged from 1.0 to $8.8 \mathrm{ppm}$ and decreased as a function of time and distance from UTPM. In Charqueadas the values ranged from 0.12 to $6.8 \mathrm{ppm}$. The variation of concentration as a function of distance passes through a minimum at about $15 \mathrm{~km}$ from UTC and subsequently increases. This may be explained due to the:presence of another power plant about $30 \mathrm{~km}$ from UTC; in the direction of the collection of samples (Usina Termoelétrica de São Jerônimo , $17 \mathrm{MW}$ ).

In both cases, the concentration of fluoride in honey decreased as a function of time of sampling and exhibited values considerably higher than in reference samples $(0.02 \mathrm{ppm})$. See Table $\nabla:$

No correlation was found between the concentration of fluoride in the samples and the distance from the respective power plants. Eight different models vere tested (Iinear, exponential, multiplicative and their variations).

The experimental results obtained for the determination of fluoride in the environmental samples of pasture and honey studied, lead to the conclusion that these materials may be used as bioindicators of pollution in areas of industrial activity.

In spite of the decreasing tendency of the values observed as a function of time in Candiota, we may generally conclude that even more recent values of fluoride concentration are above those of reference samples. This conclusion is reinforced by the occurrence of various cases of bone deformation (fluorosis) and pronounced dental wear and waste in ruminants in the vicinity 27 . A synergetic effect of fluoride adsorbed on pasture on the abrasion of coal ash deposited on sraze lands is observed. The use of samples of pasture and honey, coupled to a convenient statistical treatment, as bioindicators of pollution is recommended. They may be part of a procedure to evaluate possible contamination and consequent damages resulting from the anthropogenic dispersion of fluoride in the environment. 


\section{RERERRNCES}

1. A. Kabata-Pendias and H. Pendias "Trace Elements in Soil and Plants" CRC Press Inc., Miami, Florida, 1984, p. 214.

2. D. A. Cataldo, R. E. Wildung and T.R. Garland, Environ. Qual:, i6(4), 289-295 (1987).

3. A. Chamel and J. P. Garbec, Environ. Pollut., 22,307 (1977).

4. R. J. Taylor and F. A. Basabe, Environ. pollut. (Series A), $33(3), 221-237(1984)$.

5. D. Purves, "Trace-Element Contamination of the Environment", Elsevier Science Publishers, Amsterdam, 1985, p. 63.

6. World Health Organization (OMS), "Environmental Health, Criteria 36 - Fluorine and Eluorides", Helsinki, Finland, 1984, p. 17 .

7. E. Groth, Environment, 27, 29-37 (1975).

8. D. J. Swaine, CRC Critical Reviews in Analytical Chemistry, 25(4), 315-346 (1985).

9. 5. I. Kronberg, J.R. Brown, W. S. Fyfe, M. Pierce and C. G. Winder, Euel, 60, 59-63 (1981).

10. R. Zane11a, "Investigacão de Problemas Ambientais Relacionados com a Exploracão Intensiva e a Queima de Carvão Termoelétrico em Candiota, RS", Dissertação de Mestrado, CPGQ, Universidade Federal de Santa Maria, Santa Maria, RS, Brasil, 1983.

11. J. J. O'Toole, T. E. Hesse1s and K. L. Malaby, J. Plant Nutrition, 3, 397-407 (1981).

12. E. M. M. Flores, "Utilizaşão de Amostras Ambientais das Regiões de Candiota e de Charqueadas (RS) como Bioindicadores de Poluieão", Dissertação de Mestrado, CPGQ, Universidade Federal de Santa Maria, Santa Maria, RS, Brasil, 1990.

13. D. F. Perkins and R. 0. Ni11ar, Environ. Pollut., 48(3), $185-196$ (1987).

14. Analion, "Manual de Instrucöes do Eletrodo de Fluoreto ModeZo E656", p. 12 .

15. D. C. McCune and L.H. Weinstein, Environ. Polzut., $Z$, $169-174$ (1970).

16. H. L. Bohn, J. Environ.Qual, Z(4), 372-377 (1972).

17. Jia-Xi Wang and Mei Yong, Environ. Pollut,, $52(2), 11-18$ (1988).

18. H. W. F. Bunce, Environ. Pollut. (Series A), 35, 169-188 (1984).

19. J. Bossavy, J. Polzut. Atmos., 30, 166-184 (1966). 
20. L. J. Van der Erden, A. E. G. Tonnejk and J.K. M. Wijnands, Environ. Polzut., 53, 365-376 (1988).

21. J. Bossavy, Rev. For. Fr., 22, 533-543 (1970).

22. J. S. Jacobson, L. H. Winstein, D. C. McCune and A. E. Hitchcock, J. Air Pollut. Control Assoc., I6, 412-417 (1966).

23. I. Sunshine, "Handbook of Analytical Toxicology", Chemical Rubber Company, Akron, Ohio, USA, 1979, Fy.598-699.

24. J. P. Garrec and R. Plebin, Rev. Sci. Tot. Environ., 50, 183-189 (1986).

25. J. L. Shupe, J. Animal Sci., 5l, 746-758 (1980).

26. J. W. Suttie, J. Occup. Med., 29, 40-48 (1977).

27. F. Riet-Correa, M. D. C. Mendez, A. L. Schild and O. Zenebon, Pesq. Vet. Bras. 6(2), 23-31 (1996). 